Historia Slavorum Occidentis

2018, $\operatorname{nr} 2$ (17)

ISSN 2084-1213

DOI: $10.15804 /$ hso 180203

\author{
Mateusz Sikora (Poznań)
}

\title{
Od tamy szkieletowej do wału obronnego na Ostrowie Tumskim w Poznaniu - uwagi o konstrukcji najmłodszej linii umocnień
}

Słowa kluczowe: Poznań, wały wczesnośredniowieczne, urządzenia hydrotechniczne

Keywords: Poznan, early-medieval banks, hydrotechnical devices

\begin{abstract}
The article contains an analysis of woven fascines located under the northern part of the early-medieval defensive banks on Ostrów Tumski in Poznan. The structures, similar to the contemporary timber frame structures, had the task of accumulating the material (sand) carried by the river along the line of the planned fortifications.
\end{abstract}

Północna linia fortyfikacji poznańskiego grodu ma kształt podkowy, której ramiona kierują się ku dwóm wcześniejszym pasom obwarowań (ryc. 1) ${ }^{1}$. Inwestycja ta nadała ostateczny kształt poznańskiemu założeniu grodowemu. Kolejni Piastowie rządzący Poznaniem naprawiali lub modyfikowali obwałowania, które funkcjonowały przynajmniej od okresu rządów Mieszka I. W trakcie badań archeologicznych w 1939 r. po raz pierwszy odnotowano obecność omawianego pasa obwałowań2. Utrata dokumentacji wykopaliskowej (spowodowana działaniami wojennymi)

1 Chronologia rozwoju obwałowań grodu poznańskiego za: H. Kóčka-Krenz, Najstarszy Poznań, [w: ] Civitas Posnaniensis. Studia z dziejów średniowiecznego Poznania, red. Z. Kurnatowska, T. Jurek, Poznań 2005, s. 27-42.

2 W. Hensel, Przedmowa, [w: ] Poznań we wczesnym średniowieczu T. I, red. W. Hensel, Poznań Wrocław 1959, s. $7-12$, tu, s. 8. 
uniemożliwiła opracowanie wyników prac, które prowadzono jeszcze po 20 sierpnia 1939 r. ${ }^{3}$ Północna linia umocnień ponownie stała się obiektem badań archeologicznych dopiero w 2000 r., kiedy wykonano odwierty geologiczno-geotechniczne pod planowaną inwestycję budowlaną przy ul. Posadzego 5. W tym samym roku nadzorowano również prace wodno-kanalizacyjne w linii ulic Lubrańskiego, Dziekańskiej i Posadzego ${ }^{4}$. W wyniku wspomnianych działań zarejestrowano warstwy organiczne związane z umocnieniami wczesnośredniowiecznymi. Dopiero jednak badania archeologiczne z lat 2001-2004 r., prowadzone przez Piotra Wawrzyniaka, pozwoliły na rozpoznanie poszczególnych elementów składowych założenia obronnego oraz datowanie momentu rozpoczęcia wznoszenia konstrukcji na okres około $980 \mathrm{rr}^{5}$ $\mathrm{W}$ innym punkcie linia wałowa została uchwycona archeologicznie podczas przenoszenia w 2002 r. pomnika Jana Kochanowskiego na plac przed Akademią Lubrańskiego. W założonym wtedy wykopie o wymiarach 3,5 x 3,5 m zaobserwowano od poziomu 54,96-54,88 m n.p.m. nawarstwienia rozłożonych rusztów wałowych. Konstrukcje sięgały głębokości, na której zakończono eksplorację tj. 51,45 m n.p.m. ${ }^{6}$ Na podstawie analiz dendrochronologicznych określono chronologię elementów konstrukcji wałowych na lata siedemdziesiąte $\mathrm{X} \mathrm{w}$. ${ }^{7}$ Identyczne datowanie uzyskano po analizie prób pobranych w trakcie badań z 2006 r. prowadzonych w piwnicach budynku Akademii Lubrańskiego ${ }^{8}$. We wszystkich wykopach założonych w piwnicach oraz w części wykopów znajdujących się w pomieszczeniach akademii, zarejestrowano nawarstwienia wałowe. $\mathrm{W}$ najwyższym punkcie, warstwy wczesnośredniowiecznej fortyfikacji, zachowały się na poziomie $57,20 \mathrm{~m}$ n.p.m. O samej konstrukcji wału uzyskano niewiele informacji, odnotowano użycie techniki rusztowej, w której ułożono dranice oraz w dwóch wykopach zaobserwowano relikty skrzyń. Ławę kamienną ułożoną od czoła fortyfikacji odsłonięto przy północnej i zachodniej linii

3 Odkryto waty podgrodzia z czasów Mieszka na Ostrowie Tumskim, Kurier Poznański, 20 VIII 1939, nr 378, s. 7.

4 Za P. Wawrzyniak, Badania wykopaliskowe wczesnośredniowiecznych umocnień wałowych przy ul. ks. Ignacego Posadzego nr 5 na Ostrowie Tumskim w Poznaniu w latach 2001-2004, [w:] Poznań we wczesnym średniowieczu, t. V, red. H. Kóčka-Krenz, Poznań 2005, s. 91-110, tu, s. 91.

5 Tamże, s. 91-110.

6 P. Sankiewicz, Wczesnośredniowieczne konstrukcje obronne grodu poznańskiego, [w: ] Poznań we wczesnym średniowieczu, t. VI, red. H. Kóčka-Krenz, Poznań 2008, s. 15-27, tu, s. 15.

7 H. Kóčka-Krenz, Zarys stanu badań Instytutu Prahistorii UAM na Ostrowie Tumskim w Poznaniu w latach 1999-2004, [w: Poznań we wczesnym średniowieczu, t. V, red. H. Kóčka-Krenz, Poznań 2005, s. 9-21, tu, s. 21.

8 P. Sankiewicz, Wczesnośredniowieczne konstrukcje obronne, s. 18-21. 
fundamentów budynku akademii biskupiej, na poziomach zalegania: 53,24-52,78 m n.p.m., 52,78-52,48 m n.p.m. oraz 52,87-52,79 m n.p.m. ${ }^{9}$ Po zachodniej stronie Akademii Lubrańskiego (podczas prac w 2007 r.) również zarejestrowano warstwy rozłożonych dranic formujących wyniesienie wału. Pozostałości drewna zachowały się do wysokości: 54,07 m n.p.m. i ułożone zostały w linii NE-SW ${ }^{10}$.

Warstwy związane z najmłodszymi naprawami wału zostały uchwycone w trakcie kolejnych badań archeologicznych mających miejsce na posesji przy ulicy Posadzego 5 w 2006 r. (ryc. 1). Prace skupiały się przy linii murów obronnych wzniesionych w XVI w. Najniższe partie fundamentu przecięły, uginające się w kierunku N, konstrukcje drewniane wału (zachowane w stanie silnego rozkładu). Relikty wczesnośredniowiecznego umocnienia obronnego zalegały w tym miejscu na głębokości 55,52-54,84 m n.p.m. ${ }^{11}$

Kolejne sezony badań na ul. Posadzego 5 (w 2009 i 2010 r.) były efektem wcześniejszych prac prowadzonych w tym miejscu w latach 2001-2004. Nowe badania swoim zasięgiem obejmowały częściowo starsze wykopy. Celem tych działań archeologicznych było zadokumentowanie i zabezpieczenie profili oraz przebadanie konstrukcji wałowych na potrzeby powstającego w tym miejscu rezerwatu archeologicznego ${ }^{12}$. Charakter prac, umożliwił zatem dokładne rozpoznanie konstrukcji wałowych. Wyniki tych interdyscyplinarnych badań zostały opublikowane w VIII tomie dotyczącym Poznania we wczesnym średniowieczu ${ }^{13}$.

W trakcie wspomnianych badań linia wałów została przecięta prostopadle. Założony wykop miał wymiar 7 x $16 \mathrm{~m}$ i zorientowany był w linii N-S. Na całej powierzchni prac zarejestrowano konstrukcje skrzyniowe oraz warstwy przekładkowe, których kulminacja wystąpiła po stronie południowej wykopu. Smużki oraz całe warstwy, które je zawierały uginały się ku północy. Wykop objął zatem stok zewnętrzny wału i jak się wydaje ścianę kolejnej linii skrzyni (środkowej ?), nad którą znajdowało się najwyższe

\footnotetext{
9 Tamże, s. 19-20.

10 Tamże, s. 21.

11 P. Sankiewicz, Badania wykopaliskowe w ogrodzie posesji przy ul. ks. I. Posadzego 5 na Ostrowie Tumskim w Poznaniu w 2006 roku, Wielkopolskie Sprawozdania Ärcheologiczne 9 (2008), s. 183-193, tu, s. 186.

12 Inwestycja została zrealizowana w 2012 r. Obecnie w rezerwacie Genius loci na ul. Posadzego 3 (dawniej nr 5) można podziwiać przekrój przez wał obronny. Obiekt jest oddziałem Muzeum Archeologicznego w Poznaniu.
}

13 Poznań we wczesnym średniowieczu, t. VIII, red. H. Kóčka-Krenz, Poznań 2013. 
wypiętrzenie wału ${ }^{14}$. Przecięcie znacznego odcinka umocnień umożliwiło rozpoznane poszczególnych faz budowy. Pomocne w tym względzie było także wykonanie 121 analiz dendrochronologicznych belek stanowiących konstrukcje skrzyniowe ${ }^{15}$. Serię dat uzupełniają wyniki z wcześniejszych badań prowadzonych w latach 2001-2004, kiedy pobrano ponad 100 prób dendrochronologicznych ${ }^{16}$. Prace archeologiczne na tym odcinku nie objęly swoim zasięgiem całości przekroju wału. Dlatego trudno określić, czy konstrukcja miała symetryczny kształt i czy od strony wnętrza grodu znajdowała się podobna liczba skrzyń.

W przebadanym przekroju obwałowań pierwotnym założeniem (I fazą) są trzy rzędy skrzyń (S I, S II, S III) oraz poprzedzająca je linia skrzyń obsypana głazami - ława kamienna (EK I ${ }^{17}$. Wypiętrzenie stanowily warstwy: III g, II a oraz jedynie część warstwy określonej nr III. Ta ostatnia warstwa składa się bowiem z dwóch różnych chronologicznie nawarstwień. Starsza część, zalega na ławie kamiennej I, natomiast młodsza usypana została na późniejszej ławie kamiennej (ŁKII). Na inne datowanie części warstwy nr III wskazuje jej nachodzenie na ławę kamienną II (ryc. 3).

Rozbudowa grodu poznańskiego w północnym kierunku, podczas rządów Mieszka I, wydaje się być zabiegiem planowanym z dużym wyprzedzeniem. Samo gromadzenie materiału w postaci kłód dębowych miało trwać przez całe lata siedemdziesiąte $\mathrm{X} \mathrm{w} .{ }^{18}$ Przygotowanie odpowiedniej ilości drewna, będącego głównym elementem wału (obok ziemi oraz kamieni), wymagało czasu i równocześnie stanowiło duży wysiłek logistyczny. Szczególnie przy powiększającym się we wczesnym średniowieczu wskaźniku odlesienia Wielkopolski ${ }^{19}$. Dębina było zatem elementem składowym wału, który gromadzono w pierwszej kolejności a równocześnie część zapasów zużywano do bieżących napraw oraz prac inżynieryjnych na terenie grodu.

14 O. Antowska-Gorączniak, Badania na stanowisku przy ul. Posadzego 5 w 2009/2010 r. - charakterystyka nawarstwień, [w: ] Poznań we wczesnym średniowieczu, t. VIII, red. H. Kóčka-Krenz, Poznań 2013, s. 19-60 tu, s. 54.

15 M. Krąpiec, Dendrochronologiczne datowaniu watu grodu poznańskiego na podstawie drewna wyeksplorowanego podczas badań prowadzonych przy ulicy Posadzego 5 w 2009 r., [w:] Poznań we wczesnym średniowieczu, t. VIII, red. H. Kóčka-Krenz, Poznań 2013, s. 285-292, tu tabela I.

16 P. Wawrzyniak, Badania wykopaliskowe wczesnośredniowiecznych, s. 108.

17 Nazewnictwo rzędów skrzyń, warstw oraz ryciny za: O. Antowska-Gorączniak, Badania na stanowisku.

18 M. Krąpiec, Dendrochronologiczne datowaniu wału, s. 291.

19 M. Makohonienko, M. Kara, J. Koszałka, Przyrodnicza historia Gniezna - plemiennego ośrodka kultu i centrum wczesnopiastowskiego państwa polskiego Civitas Schinesghe, Landform Analysis 16 (2011), s. 44. 
W okresie kiedy planowano budowę wału obronnego obszar północnej części wyspy nie był zajęty przez osadnictwo. Był to teren narażony na cykliczne zatopienia przez rzekę Wartę ${ }^{20}$. Podmokły charakter potwierdzają analizy szczątków roślin pobranych z nawarstwień poprzedzających budowę umocnień. Są one charakterystyczne dla płytkich wód stojących lub wolno płynących ${ }^{21}$. Planowane zajęcie kolejnego obszaru wyspy, który był zagrożony częstymi powodziami oraz wypłukiwaniem, wymagało podjęcia prac inżynieryjnych zabezpieczających krawędź ostrowa oraz ograniczających negatywne procesy w momencie podniesionego stanu wody. Niestety, ewentualne umocnienia brzegu, które mogły zabezpieczać wyspę przed erozją, znalazły się poza obszarem wykopów prowadzonych na tym odcinku wału.

Elementami, które najczęściej wiąże się z rozpoczęciem wznoszenia konstrukcji skrzyniowych na odcinku północnym są plecionki² ${ }^{22}$ Znalazły się one bezpośrednio pod skrzyniami: SI, SII oraz ŁK I (ryc. 2:B), zatem pod najstarszą fazą umocnienia północnego. Tego typu faszyny o formie plecionych mat zaobserwowane zostały w różnych miejscach na obszarze wyspy ${ }^{23}$. Najczęściej występowanie plecionek na Ostrowie Tumskim wiąże się z potrzebą podnoszenia terenu, stabilizacją podłoża oraz wyrównywaniem gruntu pod budowę wału - taką samą rolę miały pełnić pod odcinkiem umocnień na ulicy Posadzego $5^{24}$. Na przebadanym fragmencie zarejestrowano trzy linie mat wykonane z faszyny. Pierwsza (PI) zalegała pod ławą kamienną I (częściowo wystawała przed linię kamieni) na głębokości 52,08-52,24 m n.p.m. Wypleciona została z gałęzi o średnicy 2 i $2,5 \mathrm{~cm}$ na palikach dochodzących

\footnotetext{
20 O. Antowska-Gorączniak, Badania na stanowisku, s. 52.

21 J. Koszałka, Analiza makroskopowych szczątków roślinnych, [w:] Poznań we wczesnym średniowieczu, t. VIII, red. H. Kóčka-Krenz, Poznań 2013, s. 313-323, tu s. 316.

22 O. Antowska-Gorączniak, Badania na stanowisku, s. 31-32; T. Stępnik, Wat wczesnośredniowiecznego grodu na Ostrowie Tumskim w Poznaniu przy ul. Ks. Ignacego Posadzego 5 w świetle analizy surowcowej, [w:] Poznań we wczesnym średniowieczu, t. VIII, red. H. Kóčka-Krenz, Poznań 2013, s. 269-283, tu, s. 271-272.
}

23 W. Hensel, A. Niesiołowska, J. Żak, Badania na Placu Katedralnym w 1938 roku, [w:] Poznań we wczesnym średniowieczu, t. I, red. W. Hensel, Poznań - Wrocław 1959, s. 13-57, tu s. 28; W. Hensel, Szkice wczesnodziejowe, część 1, Slavia Antiqua 2 (1949/50), s. 253-299, tu s. 275; T. Wiślański, Badania wykopaliskowe w Poznaniu na posesji Ostrów Tumski 11 w roku 1948, [w: ] Poznań we wczesnym średniowieczu, t. II, red. W. Hensel, Warszawa - Wrocław 1960, s. 7-65, tu, s. 14; A. Niesiołowska, M. Perzyńska, J. Żak, Badania na posesji Ostrów Tumski 13 w latach 1950-1953, [w: Poznań we wczesnym średniowieczu, t. II, red. W. Hensel, Warszawa - Wrocław 1960, s. 67-188, tu, s.89-90, 110; A. Nowak, Badania wykopaliskowe w ogrodzie arcybiskupim na Ostrowie Tumskim w Poznaniu w latach 1960-1961, [w: ] Poznań we wczesnym średniowieczu, t. IV, red. W. Hensel, J. Żak, Wrocław - Warszawa - Kraków - Gdańsk 1974, s. 75-144, tu, s. 90.

T. Stępnik, Wat wczesnośredniowiecznego grodu, s. 271-272. 
maksymalnie do 1,8 m długości, które rozstawiono co 45-50 cm (wysokość oplotu wynosiła $1,4 \mathrm{~m})^{25}$. Druga linia plecionek (PII) ułożona została po rzędem skrzyń (SI) na poziomie 52,3-52,14 m n.p.m. Do wyplotu użyto materiału o średnicy od 2 do $4 \mathrm{~cm}$, rozpiętego na tyczkach o długości $1,9 \mathrm{~m}$ (rozmieszczonych co 50$-63 \mathrm{~cm}$ ). Szerokość samej plecionki wynosiła 1,6 m (ryc. 2:C). Ostatnia plecionka (PIII) umieszczona została pod wewnętrznym rzędem skrzyń (SII) na gębokości 51,77-52,00 m n.p.m. Wykonano ją na żerdziach dochodzących do długości 2,25 m (średnica 3,5-4,5 cm) i rozstawionych w odstępach co 43-50 cm. Sam wyplot ma szerokość $2 \mathrm{~m}$ i wykonany został z gałęzi o średnicy o średnicy $1,5-3 \mathrm{~cm}^{26}$. Wszystkie powyższe plecionki łączy sposób wykonania, użyty podobny materiał: gałęzie jesionu (w PI), olszy (PI i PIII), brzozy (PI i PII), wierzby (PIII), dębu (PIII) i wiązu $(\mathrm{PI})^{27}$ oraz jednostronne zaostrzenie żerdzi. Przygotowanie tyczek do wbicia w podłoże przy równoczesnym braku oplotu bezpośrednio nad zaostrzeniem wskazuje na możliwość pionowego ustawienia ściany plecionki (a nie tylko w momencie jej wykonywania).

Plecionki nie znajdowały się pod całą powierzchnią najstarszej fazy wału, lecz w trzech liniach o długości kolejno: PI - 4,1 m (jej bieg kontynuuje się w profilu wschodnim wykopu); PII - płat pierwszy $3,8 \mathrm{~m}$; płat drugi 1,85 m wchodzący w profil zachodni oraz plecionkę PIII zarejestrowaną na długości 3,85 m i również wchodzącą w profil zachodni ${ }^{28}$. Takie rozmieszczenie mat faszynowych (nierównomiernie i nie pod całą konstrukcją skrzyń) sugeruje, że średniowieczni budowniczowie wału nie zakładali, że zabieg ten spowolni osiadanie (sam proces jest nieunikniony) potężnego wału. Równocześnie zastosowanie jednej warstwy plecionki pod fragmentami wału (z żerdzi o średnicy ok $4 \mathrm{~cm}$ ) nie wskazuje również na zamiar podniesienia terenu.

Chcąc zatem wyjaśnić przyczynę wykorzystania plecionych mat, należałoby uznać, że stanowily oddzielną konstrukcję, która funkcjonowała przed budową wału. Wskazuje na to także różny stan zachowania poszczególnych linii płotków faszynowych. Szczególnie posunięta destrukcja PIII (w porównaniu ze stanem zachowania PI i PII) świadczy o jej dłuższym, wcześniejszym użytkowaniu. Plecionki nie są jedynymi pozostałościami starszych konstrukcji zarejestrowanych w nawarstwieniach

\footnotetext{
25 O. Antowska-Gorączniak, Badania na stanowisku, s. 31.

26 Tamże, s. 32.

27 T. Stępnik, Wat wczesnośredniowiecznego grodu, s. 270.

28 O. Antowska-Gorączniak, Badania na stanowisku, s. 32.
} 
poprzedzających wzniesienie wału. Na przedłużeniu PII, przy profilu wschodnim zarejestrowano trzy pale dębowe o długości ok 1,2 m. Zostały one wbite pionowo w calec i zachowały się do poziomu mat faszynowych (PII). W końcach pali wykonano prostokątne otwory o wymiarach $8 \times 9-11 \mathrm{~cm}$. W linii wbitych pali oraz plecionki II zarejestrowano drobne, nieobrobione kamienie oraz dranice (o długości od 1 do $1,8 \mathrm{~m}$ ) zalegające pod matą faszynową i bezpośrednio obok ${ }^{29}$.

Zbliżone elementy konstrukcyjne wystąpiły podczas badań na posesji Ostrów Tumski 17 w 1953 r. i 1954 r. ${ }^{30}$ Zarejestrowano wtedy w VI warstwie: plecionki, wbite belki i kamienie (ryc. 4). Warstwa poniżej (VII) określona została jako calec przemieszany z warstwą następną. W warstwie VI stwierdzono obecność trzech linii plecionek, wykonanych z gałęzi dębowych oraz brzozowych, przeplecionych wokół jednostronnie zaostrzonych palików o średnicy około $10 \mathrm{~cm}$ i długich od 1 (zachowane częściowo) do $2 \mathrm{~m}$. Największa z trzech mat miała długość $11 \mathrm{~m}$ i szerokość $2 \mathrm{~m}$. Dwie kolejne linie plecionek, zachowane w swoich dolnych partiach do wysokości 0,5 m i długie na ok. $4 \mathrm{~m}$, nakładały się na najdłuższy płat. W tej warstwie na linii plecionek (przez całą długość wykopu) wystąpiły pionowo wbite kołki (nienaruszające faszyny) oraz kamienie polne. Całość znajdowała się po północnej stronie naturalnego piaszczystego wyniesienia. Autorka opracowania zakłada, że plecionki odsłonięto in situ i nie służyły do wymoszczenia podłoża, a funkcjonowały wbite pionowo (choć nie wskazuje ich przeznaczenia) ${ }^{31}$. Warstwa VI, w której zalegały maty z faszyny, datowana jest na okres nie późniejszy niż połowa $\mathrm{X}$ w., a zalegające na niej kolejno warstwy Vd i Vc na początek XI w. ${ }^{32}$ Warstwy Vd i Vc są warstwami o charakterze nasypowym i wyrównującym o miąższości kolejno: warstwa Vd od 0,1 po ok. $0,5 \mathrm{~m}$ oraz warstwa Vc od 0,08 do 0,20 m. Warstwę Vd tworzyły porozrzucane gałązki sosnowe oraz brzozowe, wzmocnione rzędami kołków. Natomiast warstwa Vc powstała poprzez ułożenie od południa konstrukcji drewnianych: legarów z nieokorowanych pni sosnowych, na których ułożono poprzecznie pnie brzozy i sosny ${ }^{33}$. Podnoszenie warstw, przygotowujących nowy obszar grodu bezpośrednio pod osadnictwo, musiało się odbywać dopiero po osłonięciu tego terenu od powodzi, czyli

\footnotetext{
29 O. Antowska-Gorączniak, Badania na stanowisku, s. 31.

30 M. Malinowska, Badania na stanowisku Ostrów Tumski 17 w Poznaniu w latach 1953-1954, [w: ] Poznań we wczesnym średniowieczu, t. III, red. W. Hensel, Warszawa - Wrocław 1961, s. 7-95, tu s. 9-10.

31 Tamże, s. 10-11.

32 Tamże, s. 14, 22, 32.

33 Tamże, s. 14, 22.
} 
po wybudowaniu wału obronnego (około 980 r.), ewentualnie warstwy nasypowe podnoszono równocześnie $\mathrm{z}$ usypywaniem wału. Zatem datowanie warstw Vd i Vc należałoby przesunąć na ostatnie dwudziestolecie $\mathrm{X}$ w. Określenie chronologii warstwy VI (z plecionkami) na połowę X w. opiera się na materiale ceramicznym, który deponowany był na tym zalewowym obszarze jako odpadki pochodzące $\mathrm{z}$ funkcjonujących partii grodu (tzw. książęcej i katedralnej).

Zarówno plecionki pod wałem na ul. Posadzego 5, jak i zalegające w najstarszej warstwie wyróżnionej podczas badań na posesji Ostrów Tumski 17, stanowią starsze konstrukcje poprzedzające zajęcie przez gród północnej części wyspy. Składają się z podobnych elementów: belek wbitych w calec, kamieni polnych oraz plecionek rozciągniętych na zaostrzonych żerdziach. Poziomy, na których zalegały (i zapewne funkcjonowały) również były zbliżone. Na stanowisku Posadzego 5 znajdowały się na poziomie: od 51,77 po 52,24 m n.p.m. a na stanowisku Ostrów Tumski 17 na wysokości 51,90 do 52,28 m n.p.m.

Funkcjonowanie grodu na wyspie wymagało ciągłych działań hydrotechnicznych, związanych z zabezpieczeniem brzegów wyspy, wałów czy infrastruktury znajdującej się po zewnętrznej stronie umocnień, zarówno podczas normalnego jak i podniesionego stanu wód. Prócz działań zabezpieczających wznoszono konstrukcje, których zadaniem było regulowanie rzeki. Omówione plecionki stanowiły pozostałość tego typu konstrukcji. W terminologii hydrologicznej należały do budowli regulacyjnych typu lekkiego. Zadaniem różnorodnych tego typu konstrukcji, o najczęściej przepuszczalnej formie, jest kierowanie prądem wody i wywoływanie pogłębiania lub spłycania dna. Można ograniczać takimi budowlami zbyt szerokie kory to rzeki oraz doprowadzać do zarastania przestrzeń poza liniami regulacyjnymi. Lekkie drewniane konstrukcje ustawiane są jako budowle pomocnicze i w momencie spełnienia zadania lub ich zniszczenia ( $w$ obu przypadkach ma to miejsce po kilku powodziach) są usuwane lub przebudowywane ${ }^{34}$. Woda przepływając przez lekkie konstrukcje nie zmienia swojego kierunku, lecz wywołuje zjawiska np. akumulacyjne. Pożądanym było wytworzenie ławic i odsypów w linii projektowanych cięższych budowli regulacyjnych (np. wałów). Duża ilość form, stosowanych obecnie w poszczególnych rejonach świata konstrukcji przepływowych lekkich, wynika $\mathrm{z}$ ich prostoty ${ }^{35}$. Kiedy uzyska się wymagany poziom akumulacji nanosów, zastępuje się je wtedy właściwymi, docelowymi obiektami. W przypadku Ostrowa Tumskie-

\footnotetext{
34 J. Wołoszyn, W. Czamara, R. Eliasiewicz, J. Krężel, Regulacja rzek i potoków, Wrocław 1994, s. 409.

35 Tamże, s. 410-411.
} 
go były nimi wały obronne. Konstrukcje typu lekkiego były używane ciągle w początkach XIX w. Na potrzebę budowy płotków wzdłuż brzegów Wisły, a następnie skierowanie na nie wody i docelowo zasypanie konstrukcji niesionym przez rzekę piaskiem - wskazywał Józef Sadkowski w raporcie z 20 III 1811 r. Był on Budowniczym Departamentu Radomskiego i miał ustalić niezbędne do wykonania prace, które miały uregulować Wisłę oraz ograniczyć niszczącą działalność powodzi ${ }^{36}$.

Plecionki z obszaru północnego członu grodu poznańskiego najbardziej przypominają używane dziś tamy szkieletowe, które regulują rzekę. Te lekkie i przepuszczające konstrukcje mają formę dwóch rzędów palików wypełnionych faszynami. Całość obciąża się kamieniami (ze względu na lekkość konstrukcji). Tamy szkieletowe stosuje się na obszarach okresowo poddanych zalewaniu. Podłużna tama szkieletowa jest zalewana z dwóch stron wodą. Faszyna rozbija energię kinetyczną wody (hamuje procesy erozyjne), sprzyja „zalądowywaniu” otoczonych terenów ${ }^{37}$ przez zatrzymywanie po stronie lądu materiału niesionego przez rzekę.

Zarejestrowane w czasie badań archeologicznych na ulicy Posadzego 5 i Ostrów Tumski 17 konstrukcje plecionek (wraz z belkami oraz kamieniami) tworzyły zatem konstrukcję zbliżoną do tamy szkieletowej. Miała ona formę szerokiego płotu ograniczonego z dwóch stron plecionkami i wypełnionego faszyną, dodatkowo obciążonego kamieniami i ustabilizowanego wbitymi w podłoże szerszymi belkami. Zadaniem tej konstrukcji była ochrona przed erozją znajdujących się na południe wałów oraz nagromadzenie materiału przenoszonego przez Wartę w celu podniesienia całości poziomu gruntu na obszarze zalewowym. Naniesiony materiał miał ułatwić zasiedlenie i wzniesienie na nim stałych konstrukcji - wałów obronnych. Niszczone w wyniku powodzi elementy konstrukcyjne tamy wymagały napraw, co tłumaczy różny stan zachowania plecionek odsłoniętych pod wałem na ulicy Posadzego 5. Dwa blisko położone miejsca zalegania plecionek (ul. Posadzego 5 i Ostrów Tumski 17) wskazują na możliwość funkcjonowania jednej linii tamy (o nieregularnym kształcie). Bardziej prawdopodobne jest jednak wznoszenie w różnym czasie kolejnych opasek z tam szkieletowych. Z każdą kolejną tamą odchodzono od istniejącego ówcześnie grodu, aż do momentu otoczenia całości terenu przeznaczonego pod zasiedlenie oraz budowę fortyfikacji. W tym przypadku tama znajdująca się pod wałem, nie byłaby jeszcze tamą zewnętrzną.

36 J. Jaśkiewicz, Wykorzystanie i zabezpieczenie Wisty w XVIII/XIX w., Kwartalnik Historii Kultury Materialnej 22 (1984), nr 1, s. 59-65.

37 W. Begemann, H. M. Schiechtl, Inżynieria ekologiczna w budownictwie wodnym i ziemnym, Warszawa 1999, s. 111-112. 
Wznoszenia tego typu konstrukcji hydrotechnicznych w tej części wyspy można określić na czas od momentu budowy drugiego członu grodu (połowa $\mathrm{X}$ w.) po rozpoczęcie budowy umocnienia północnego (lata osiemdziesiąte $\mathrm{X}$ w.). Pierwsze tamy mogły być wznoszone po to, aby regulować prąd rzeki Warty. Kiedy jednak w latach siedemdziesiątych rozpoczęto gromadzenie kłód dębowych pod budowę wału, zapewne również prace hydrotechniczne ukierunkowano na nagromadzenie jak największej ilości materiału niesionego przez rzekę. A już samo rozpoczęcie budowy wału wymagało rozplantowania konstrukcji tamy: faszyn, kamieni i plecionek.

Budowa ostatniej, najmłodszej linii wałów była zatem planowana i przygotowywana. Samo wypiętrzenie wału rozpoczęto stawiać na początku lat osiemdziesiątych. Inwestycja zbiegła się z planami zajęcia centralnej przestrzeni drugiego członu grodu (wschodniego). Właśnie bowiem wtedy mogła rozpocząć się budowa katedry poznańskiej w związku z możliwą konsekracją Ungera w 982 r. na biskupa z siedzibą w Poznaniu ${ }^{38}$. Czy te dwie inwestycje były ze sobą powiązane? Możliwe, że zapewnienie nowej ufortyfikowanej przestrzeni, w zastępstwie obszaru zajętego przez katedrę, warunkowało rozpoczęcie wznoszenia świątyni.

Kolejnym interesującym elementem konstrukcyjnym, który został odsłonięty w czasie badań prowadzonych na ulicy Posadzego 5, są cztery belki wbite pionowo oraz ukośnie w przerwę pomiędzy skrzyniami w rzędzie II (SII) (ryc. 2:A). Jest to pewne zakłócenie w całej konstrukcji wału. Zakłada się, że tak wstawione belki (piloty) miały za zadanie wzmacniać miejsce łączenia się skrzyń ${ }^{39}$. Już wcześniej zauważono stosowanie pilotów, do wiązania rozrzuconych belek w częściach fundamentowych wału poznańskiego ${ }^{40}$. W przypadku odcinka umocnień przebiegającego na stanowisku Posadzego 5, piloty (4 sztuki), zostały wbite gęsto wzdłuż jednego z boku skrzyni i blokowały ułożone na niej podłużne dranice. Osadzone pionowo belki zabezpieczały krawędź skrzyni do wysokości zachowania konstrukcji hakowych. Potrzeba wzmocnienia boku skrzyni wskazuje na brak oparcia o kolejne skrzynie, które z jakiegoś powodu nie zostały jeszcze ułożone. Założyć zatem można, że na linii pilotów kończył się pewien etap prac. Na tej samej osi kończyła się również skrzynia w sąsiednim rzędzie izbic (SI). Równoczesne ukończenie skrzyń podyktowane było zmianą w następnych izbicach. Zaczęto bowiem od tej linii for-

\footnotetext{
38 A. Bukowska, Najstarsza katedra w Poznaniu, Kraków 2013, s. 254-257.

39 O. Antowska-Gorączniak, Badania na stanowisku, s. 33.

40 W. Hensel, Stowiańszczyzna wczesnośredniowieczna: zarys kultury materialnej, Warszawa 1956, s. 353.
} 
mować łuk wału. Od tego momentu belki ułożone od czoła skrzyń ustawione zostały pod wyraźnym skosem (ryc. 2:A). Po zachodniej stronie linii pilotów, belki w SI oraz SII ustawiono na osi W-E i pod kątem prostym do bocznych belek skrzyń. Po wschodniej stronie znajdował się początek łuku biegnącego z zachodu na wschód. Rozpoczęcie zagięcia wału mogło wymagać dokładnego wskazania przebiegu linii konstrukcji skrzyniowej, aby zachować ciągły (bez załomów) przebieg umocnienia. Mogło to wymusić wstrzymanie prac. Wbite piloty, są zatem śladem organizacji pracy przy budowie umocnień obronnych. Możliwe, że linia pionowo wbitych pali wyznacza również, podobnie jak przy wznoszeniu wału grodu gnieźnieńskiego, granicę prac poszczególnych grup ludności w ramach posług związanych $\mathrm{z}$ budową i naprawą umocnień ${ }^{41}$. W omawianym fragmencie wału poznańskiego podział na dwa sąsiednie odcinki jest zauważalny również powyżej wbitych belek. Zarejestrowano bowiem wykorzystanie innego wypełnienia pomiędzy warstwami dranic w poszczególnych stosach. W rusztach znajdujących się od wschodu w skrzyniach z linii SI i SII, użyto przesypki ze znaczną domieszką gliny - innej niż w pozostałych skrzyniach po stronie zachodniej w SI i SII (w nich używano głównie piasku rzecznego).

Pierwszą poważną przebudowę wału wykonano w początkach XI w. Poszerzono wówczas konstrukcję wału o trzy rzędy skrzyń: ławę kamienną II (ŁKII), ławę drewniano-ziemną I (ŁDZSI) oraz ławę drewniano-ziemną II (ŁDZSII). Ława kamienna została utworzona z kamieni w skrzyniach o konstrukcji hakowo-zrębowej. Wymiary skrzyń wynosiły 4,3/4 x 3 m, a ich rekonstruowana wysokość sięgała 1m. Natomiast wypełniające je kamienie usypane zostały do wysokości 1,65 m oraz na 2,85 m szerokości. Kolejne dwa rzędy skrzyń: ŁDZSI oraz ŁDZSII, miały wymiary u podstawy kolejno 3,40 x 3,3/3 m oraz 4,6 x 2,35 m. Izbice w ławach zewnętrznych wypełnione zostały rusztami kładzionymi w technice przekładkowej (ŁDZSI) oraz belkami dębowymi ułożonymi w kratownicę i wzmocnionymi pilotami (ŁDZSII) ${ }^{42}$. Nie można z całą pewnością stwierdzić, że nie było kolejnych zewnętrznych skrzyń. Mogły one być doprowadzone do krawędzi wyspy, gdzie kolejne wzmocnienia na bieżąco hamowały procesy erozyjne wywołane falami podczas niskich stanów Warty. Umocnienia zewnętrzne (ŁDZSI, ŁDZSII), przed ławą kamienną II, miały za zdanie powstrzymywać podmywanie wyspy bezpośrednio przed wałem. Było to największe zagrożenie dla stabilności wału. $\mathrm{Z}$ tego powodu krawędź samego wypiętrzenia

41 K. Żurowski, Konstrukcje obronne wczesnośredniowiecznego Gniezna, Archeologia Polski 1 (1957), s. 180-212, tu, s. 196-197, ryc. 19.

42 O. Antowska-Gorączniak, Badania na stanowisku, s. 38-39. 
obsypywana była zarówno w I fazie jak i II fazie ławą kamienną, która miała chronić przed falami w momencie średniego wezbrania Warty. Na ławę kamienną późniejszą, nałożono konstrukcje drewniano-ziemne (górne partie warstwy III). Powiększenie wału o nową ławę kamienną, dodanie zewnętrznych linie skrzyń oraz ułożenie nowego wypiętrzenia, miało miejsce w początkach XI w. Datowanie inwestycji precyzuje analiza pobranej próby dendrochronologicznej (nr PZN524) z ŁDZSI wskazująca na pozyskanie dębu podczas ścinki zimowej na przełomie 1000 i $1001 \mathrm{r}^{43}$

Wcześniejsze badania datowały rozbudowę wałów w okresie rządów Bolesława Chrobrego na lata po 1009 r. ${ }^{44}$ Daty 1001 r. i 1009 r. ustalone zostały o wyniki analizy materiału dendrochronologicznego z konstrukcji skrzyń z zewnętrznych ław (ŁDZSI i ŁDZSII). Konstrukcje wznoszone były zatem w przeddzień lub w trakcie konfliktu polsko - niemieckiego z lat 1002-1018. W momencie wybuchu wojny w 1002 r. rozbudowa wału mogła trwać już od ponad roku (po 1009 r. byłaby naprawiana). W pierwszej fazie wzniesiono ławę kamienną II oraz wsparte na niej ruszty drewniane. W pozyskanych do tej pory próbach dendrologicznych pobranych z drewnianych konstrukcji wałowych na obszarze całego grodu, brak informacji o przebudowie w tym czasie innych partii umocnień (co może być wynikiem stanu badań). Przygotowanie obwarowań grodowych do ewentualnego szturmu musiało mieć jednak miejsce. Szczególnie podczas trwania niemieckiej wyprawy na państwo Piastów w 1005 r. Bolesław Chrobry, opóźniając marsz wojsk cesarsko-czesko-wieleckich oraz atakując je z zasadzek, osłabiał siły przeciwnika. Równocześnie dawał czas na przygotowanie wybranych grodów do obrony. Władca chroniąc się w Poznaniu sam wybrał miejsce i czas ewentualnego rozstrzygnięcia siłowego. Osłabienie wojsk niemieckich oraz umocnienia poznańskie były powodami, które sprawiły, że konflikt zakończony został zawarciem pokoju na Ostrowie Tumskim w Poznaniu.

Kolejny etap wzmocnienia wału datowany jest na okres po 1009 r. Naprawie poddano ówcześnie zewnętrzne linie wału: skrzynie drewniano-ziemne zatopione w poziom gruntu wyspy (ŁDZSI i ŁDZSII), poniżej lawy kamiennej. Powodem prac wzmacniających przedpole wału było zagrożenie wymywania krawędzi wyspy, co w dalszej kolejności mogło spowodować obsunięcie konstrukcji wałowej.

Ciągłe zagrożenie powodziami sprawiało, że wały obronne grodu poznańskiego starano się chronić przed destrukcyjną działalnością wody. Przy niskim i średnim poziomie rzeki, wał chroniła ława kamienna, która działała jak falochron. W momen-

43 M. Krąpiec, Dendrochronologiczne datowaniu watu, s. 291.

44 P. Wawrzyniak, Badania wykopaliskowe wczesnośredniowiecznych, s. 108. 
cie, kiedy poziom wody był wyższy, woda wypłukiwała piasek oraz elementy rusztów ze stoku wałowego. Sytuacja taka wystąpiła w okresie po zakończeniu rozbudowy wału za rządów Bolesława Chrobrego. Woda wymyła wypełnisko warstwy III - znad ławy kamiennej II, do granicy ławy kamiennej I. Grunt powyżej gwałtownie opadł, co wywołało przesunięcie się nawarstwień w obrębie warstwy III. Widoczna linia uskoku ${ }^{45}$ przecinająca smużki oraz warstwy ziemi wskazuje, że drewno stanowiące warstwę III, w czasie obsunięcia było już w wyraźnym stanie rozkładu (ryc. 3). Wypłukane warstwy uzupełniono warstwą IIIb. Kolejne warstwy stanowiące wzmocnienie wału: IIIc i IIId zostały usypane bez ławy kamiennej odpowiednio w XI oraz pomiędzy XI i pierwszą połowę XIII w. ${ }^{46}$

Wały północnego członu grodu poznańskiego zostały w ostatnich latach dokładnie rozpoznane. Jest to zasługa wielosezonowych prac prowadzonych na ulicy ks. Ignacego Posadzego 5. Znaczny obszar prowadzonych badań umożliwił zebranie informacji dotyczących technik wznoszenia wczesnośredniowiecznych fortyfikacji w okresie piastowskim.

Potężna konstrukcja wzniesiona w końcu panowania Mieszka I została dokładnie zaplanowana. Wcześniej zgromadzono drewno dębowe potrzebne do budowy, ustawiono również płoty plecionkowe (zbliżone do tam szkieletowych) w celu skumulowania materiału niesionego przez rzekę na obszarze zalewowym. W trakcie prowadzenia prac budowa dzielona była na etapy i dokładnie planowana oraz nadzorowana. Świadczy o tym staranne przygotowanie wyprowadzenia łuku obwarowań.

Powiększenie w stronę północną grodu nastąpiło w czasie, kiedy zachodziły zmiany w zagospodarowaniu terenów wcześniejszych obwarowań - po $980 \mathrm{r}$. Rozpoczynano wtedy budowę katedry, co wiązało się z zajęciem na cele religijne praktycznie całego majdanu dotychczasowego członu drugiego (powstały mieszkania dla duchownych, plac przed katedrą oraz obejście wokół świątyni). Nasuwa to przypuszczenie, że budowa ostatniego pierścienia wałów powiązana była ściśle z planowaniem budowy katedry. Nie zostało również rozstrzygnięte czy gród od lat osiemdziesiątych miał formę czteroczłonową, czy zachowano dotychczasowy układ rozbierając część umocnień członu II. By uzyskać informacje na temat wewnętrznego podziału umocnień należałoby podjąć szeroko zakrojone badania, o skali porównywalnej z pracami przeprowadzonymi na ul. Posadzego 5.

45 Tamże, s. 97.

46 O. Antowska-Gorączniak, Badania na stanowisku, s. 38-39. 
Nadesłany: 3 V 2018

Nadesłany po poprawkach recenzyjnych: 10 VI 2018

Zaakceptowany: 11 VI 2018

mgr Mateusz Sikora

Rezerwat Archeologiczny Genius loci

Muzeum Archeologiczne w Poznaniu

ul. Wodna 27

61-781 Poznań

mateusz.sikora@rezerwat.muzarp.poznan.pl

\section{From a timber frame dam to a defensive bank on Ostrów Tumski in Poznan - comments on the structure of the youngest line of the fortifications}

The author analysed woven fascines located under the northern piece of the defensive banks of the Poznan stronghold (registered at the 5 Posadzego site) and identified them as remains of hydro-technical infrastructure. The structures, similar to the contemporary timber frame structures, had the task of accumulating the material (sand) carried by the river along the line of the planned defensive banks. Similar structures had been discovered in the northern part of the 17 Ostrów Tumski site yet their function was not identified. The author also presents the chronology of the specific phases of the bank construction (based on the results of tree-ring-dating) and structure elements (pilots, starlings, the bank's turn, stone foundations). This is also an indication of an intended constructing the Poznan cathedral as the possible reason for extending the range of the fortifications around 980 .

Translated by: Ewa Dratwa 


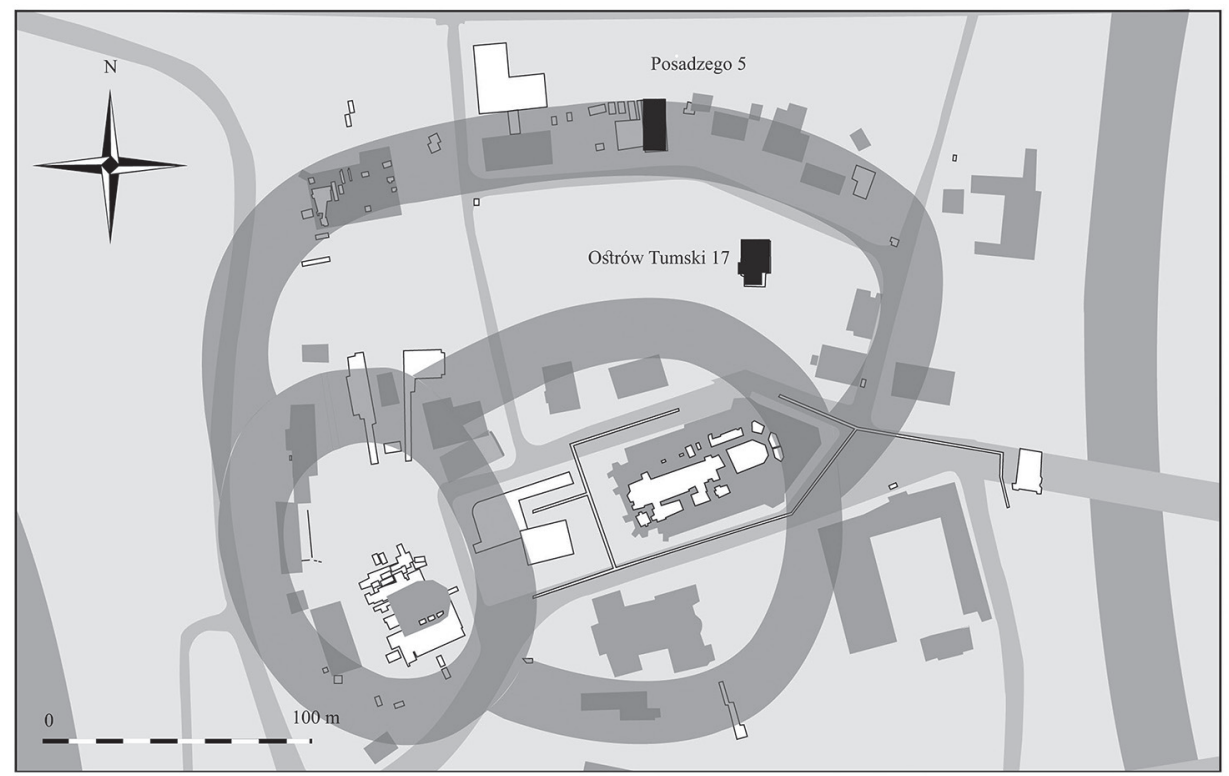

Ryc. 1. Część środkowa i północna założenia grodowego na Ostrowie Tumskim w Poznaniu. Rys. O. Antowska-Gorączniak, uzup. aut. (Figure 1. The central and northern parts of the Ostrów Tumski stronghold in Poznan. Drawing by O. Antowska-Gorączniak, supplemented by the author). 

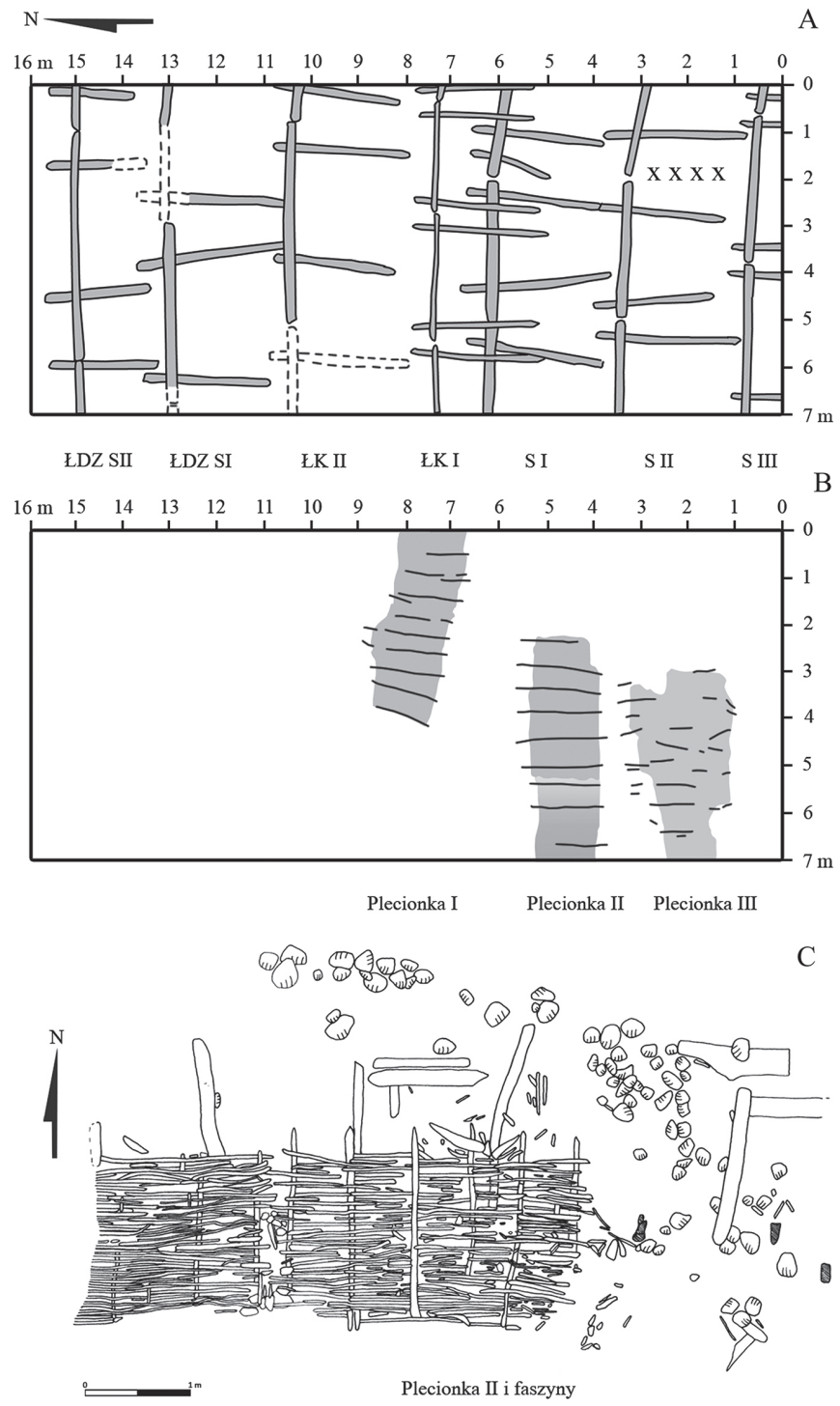

Ryc. 2. Konstrukcje u podstawy wału - ul. ks. I. Posadzego 5, Poznań. 2: A. Rozmieszczenie konstrukcji skrzyniowo-hakowych (x-zaznaczone piloty); 2: B. Rozmieszczenie plecionek; 2:C. Plecionka II. Rys. O. Antowska-Gorączniak, uzup. aut. (Figure 2. The structures at the base of the bank - 5 ks. I. Posadzego Street, Poznan. 2:A. Distribution of the box-and-hook structures (x marks the pilots); 2:B. Distribution of the woven structures; 2:C. Woven structure II. Drawing by $\mathrm{O}$. Antowska-Gorączniak, supplemented by the author). 


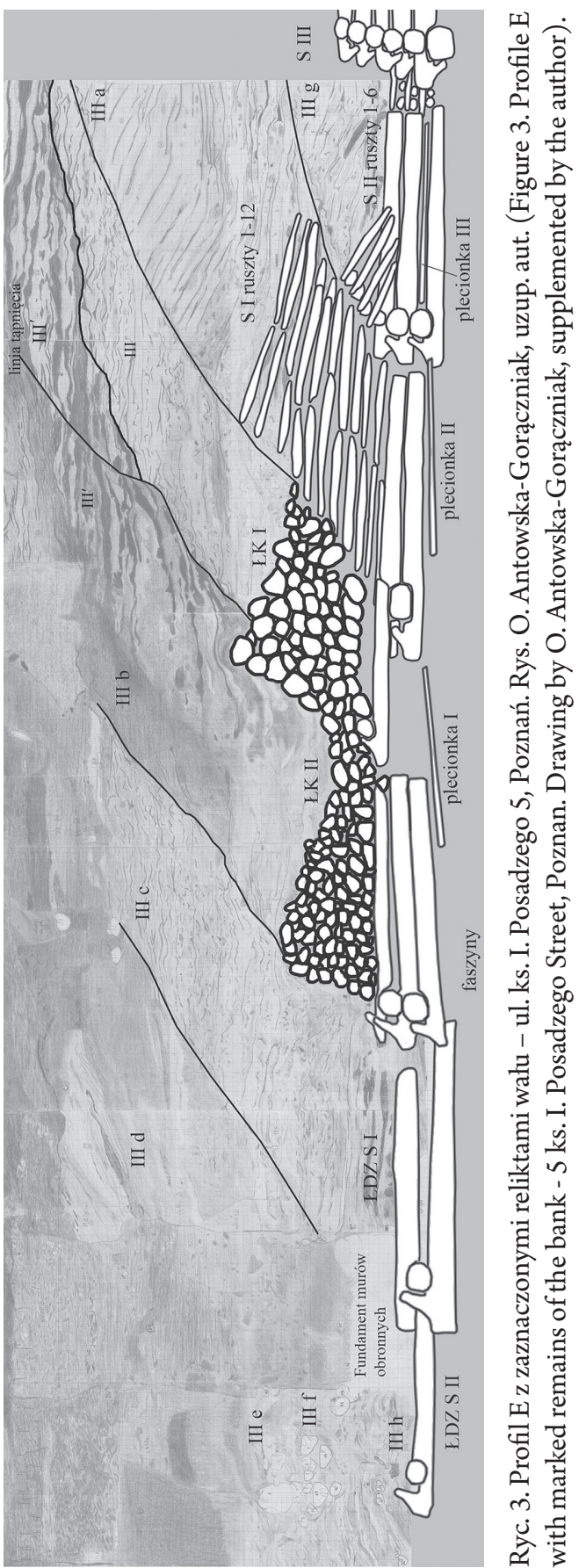






Ryc. 4. Konstrukcje plecionkowe - Ostrów Tumski 17, Poznań. Rys. L. Fijał.(Figure 4. Woven structures - 17 Ostrów Tumski, Poznań. Drawing by L. Fijał). 